\title{
Immunoglobulin Metabolism in Ataxia Telangiectasia
}

\author{
Warren Strober, R. Dean Wochner, Mahlon H. Barlow, \\ Dale E. McFarlin, and Thomas A. WaldmanN \\ From the Metabolism Branch, National Cancer Institute and the Medical \\ Neurology Branch, National Institute of Neurological Diseases and \\ Blindness, National Institutes of Health, Bethesda, Maryland 20014
}

A в S T R A C T Immunoglobulin metabolism has been studied in five patients with ataxia telangiectasia and in control subjects. Serum IgG levels were normal, increased, or decreased, reflecting normal, increased, or decreased synthetic rates, respectively. Serum IgM concentration was normal in three cases and slightly elevated in two cases. IgM turnover studies in the three cases with normal serum IgM levels showed normal IgM synthetic and catabolic rates. None of the five patients with ataxia telangiectasia had detectable serum $\operatorname{IgA}$, and the maximum $\operatorname{IgA}$ synthetic rates possible for these patients were $0.3-10 \%$ of the normal mean synthetic rate $(24 \pm 15 \mathrm{mg} / \mathrm{kg}$ per day) of 12 control individuals. Three of the patients had normal IgA fractional catabolic rates: $22 \%$ of the intravascular pool per day vs. $25 \pm$ $4 \%$ in controls. In two patients, fractional catabolic rates 4 and 20 times normal were found. In these cases, metabolic turnover, in vitro precipitation, radioimmunoelectrophoresis, and (or) the $C^{\prime} 1 \mathrm{a}$ fixation and transfer test provided evidence for the presence of a circulating antibody directed against IgA causing immune elimination of the molecule. These studies suggest that therapy with exogenous IgA may not be possible in some patients with ataxia telangiectasia or in other subjects with dysgammaglobulinemia.

\section{INTRODUCTION}

The recognition of distinct immunoglobulin classes has led directly to studies of specific immunoglobu-

Address requests for reprints to Dr. Warren Strober, Clinical Center 4N116, National Institutes of Health, Bethesda, Md. 20014.

Received for publication 22 February 1966 and in revised form 29 April 1968. lin metabolism and function. Ataxia telangiectasia is of considerable interest in this connection since it has been associated with $\operatorname{Ig} \mathrm{A}$ deficiency and other immunologic abnormalities (1-11).

Ataxia telangiectasia is characterized by cerebellar ataxia and oculocutaneous telangiectasia $(12,13)$. Associated clinical findings in some patients have been recurrent sinopulmonary infection $(1,5,6)$ and reticuloendothelial neoplasm $(2,12)$. Immunologic defects have been reported in many patients. These defects include: $(a)$ delayed skin homograft rejection and decreased response to tuberculin-type skin antigens $(2,4,10) ;(b)$ decreased circulating antibody response to antigenic stimulation $(2,9) ;(c)$ lymphocytopenia with abnormal lymph node architecture $(2,4,6,8) ;(d)$ thymic abnormalities including both absence of thymus and histologically abnormal thymus $(2,5)$; and $(e)$ a somewhat heterogeneous dysgammaglobulinemia (1-11).

Among the most striking of the immunologic defects is the dysgammaglobulinemia. Normal persons produce three major classes of immunoglobulins: IgG $\left(\gamma_{2}, \gamma_{\mathbf{s s}}\right), \operatorname{IgA}\left(\gamma_{1} \mathrm{~A}, \beta_{2} \mathrm{~A}\right)$, and $\operatorname{Ig} \mathrm{M}\left(\beta_{2} \mathrm{M}, \gamma \mathrm{M}\right)$. In patients with ataxia telangiectasia who were studied to determine immunoglobulin levels (1-11), 43 of 58 showed marked reduction or absence of $\operatorname{IgA}$, whereas in 1 of 58 there was an increased IgA level, and in 14 of 58, normal levels were present. In the deficient or absent IgA group, three patients had an associated IgG deficiency (2), and five others had borderline IgG decreases $(2,6)$; in addition, marginal increases in IgG levels have been seen (6). Also within this group, at least 10 instances of increased $\operatorname{IgM}(2,3,6,7)$ and two instances of decreased IgM levels have been recorded $(2,8)$. 
In the present study, the metabolism of the immunoglobulins was studied in five patients with ataxia telangiectasia. Immunoglobulin levels were measured in the serum of these patients with a specific immune precipitation technique. In addition, immunoglobulin turnover studies were performed to determine total body protein pools and rates of degradation and synthesis of the various immunoglobulins. A pronounced defect in $\operatorname{IgA}$ synthesis and, in some cases, a shortened survival of $\operatorname{Ig} \mathrm{A}$ was demonstrated in these patients with ataxia telangiectasia.

\section{METHODS}

Patient material. Five patients with ataxia telangiectasia were studied. A summary of pertinent clinical data is presented in Table I. Patients ranged in age from 11 to $19 \mathrm{yr}$; four of the five were females. The diagnosis was established by the presence of ataxia and ocular and (or) cutaneous telangiectasia. Extensive neurological evaluation was done in each case to exclude other causes of ataxia and other congenital neurologic diseases.

The infectious history of these patients is as follows: two patients (G.N.L. and G.V.L., ages 18 and 19) were without any significant history of recurrent infection. A third patient (P.G., age 14) gave a history of recurrent respiratory infection, including pneumonia, several years before admission (from age 6 to $9 \mathrm{yr}$ ), which was controlled with adequate pulmonary drainage; this patient had considerable difficulty controlling respiratory secretions. A fourth patient (D.R., age 10) had a history of chronic postnasal drip without evidence of sinusitis by $x$-ray; in the several weeks before study, she had a lowgrade fever which was never well explained; in this case there was a single episode of otitis media which led to adenoidectomy. The fifth patient (G.R., age 14) had a history of chronic cough without acute lower respiratory infection. All patients had normal chest films and chest examinations during the period of study.

IgA turnover studies were performed on three patients with abnormal IgA levels but who did not have ataxia telangiectasia. These included: $(a)$ a $70 \mathrm{yr}$ old woman with myeloma and IgA paraprotein who was on phenylalanine mustard therapy; $(b)$ a $45 \mathrm{yr}$ old woman with acquired "idiopathic" hypogammaglobulinemia ; and (c) a $38 \mathrm{yr}$ old woman with IgG hypergammaglobulinemia, isolated absence of serum $\operatorname{IgA}$, and a history of respiratory infections.

Control patients. Normal volunteers were used as controls in IgG and IgM turnover studies. Patients with various neurological and neoplastic diseases were used as controls in $\operatorname{IgA}$ turnover studies. These included four patients with myotonic dystrophy, two patients with

TABLE I

Clinical Data and Laboratory Data

\begin{tabular}{|c|c|c|c|c|c|c|c|c|c|c|c|}
\hline \multirow[b]{2}{*}{ Subject } & \multirow[b]{2}{*}{ Age } & \multirow[b]{2}{*}{ Sex } & \multirow[b]{2}{*}{ Neurological history } & \multirow[b]{2}{*}{ History of infections } & \multirow[b]{2}{*}{$\begin{array}{c}\text { Lymphocyte } \\
\text { levels }\end{array}$} & \multirow{2}{*}{$\begin{array}{l}\text { Bone } \\
\text { marrow } \\
\text { morphology }\end{array}$} & \multicolumn{5}{|c|}{ Serum electrophoresis } \\
\hline & & & & & & & $\begin{array}{l}\text { Albu- } \\
\min \end{array}$ & $\alpha_{1}$ & $\alpha_{2}$ & $\beta$ & $\gamma$ \\
\hline G. V. L. & 19 & 웅 & $\begin{array}{l}\text { Onset of neurological } \\
\text { dysf unction at age } 5 . \\
\text { Conjunctival and } \\
\text { skin telangiectasia } \\
\text { at age } 8 \text {. }\end{array}$ & $\begin{array}{l}\text { Measles, varicella, pertussis. No } \\
\text { sequellae. Negative respiratory } \\
\text { or allergic history. }\end{array}$ & $1703 / \mathrm{mm}^{3}$ & Normal & 4.1 & 0.3 & 0.6 & 1.1 & 1.4 \\
\hline $\begin{array}{l}\text { G. N. L. } \\
\text { (sister of } \\
\text { G. V. L.) }\end{array}$ & 18 & \% & $\begin{array}{l}\text { Onset of ataxia and } \\
\text { oculocutaneous } \\
\text { telangiectasia at } \\
\text { age } 6 .\end{array}$ & $\begin{array}{l}\text { Measles, mumps, varicella. No } \\
\text { sequelae. Negative respiratory } \\
\text { or allergic history. }\end{array}$ & $1787 / \mathrm{mm}^{3}$ & Normal & 3.6 & 0.2 & 0.7 & 0.7 & 1.1 \\
\hline P. G. & 16 & $\sigma^{7}$ & $\begin{array}{l}\text { Prominent conjunctival } \\
\text { vessels at birth. } \\
\text { Cutaneous telangiec- } \\
\text { tasia at age } 7 . \text { Ataxia } \\
\text { noted with initial } \\
\text { walking attempts. }\end{array}$ & $\begin{array}{l}\text { Several episodes of otitis before } \\
\text { age 3. Age 4-10, frequent UR Is. } \\
\text { Pneumonia diagnosed at age } \\
\text { one. Since age } 10 \text { no respira- } \\
\text { tory infections of note. No } \\
\text { allergies. }\end{array}$ & $815 / \mathrm{mm}^{3}$ & Normal & 4.5 & 0.4 & 0.7 & 0.9 & 0.4 \\
\hline G. R. & 14 & 웅 & $\begin{array}{l}\text { Ataxia noted at age } 1 . \\
\text { Conjunctival telan- } \\
\text { giectasia at age } 8 . \\
\text { No cutaneous } \\
\text { telangiectasia. }\end{array}$ & $\begin{array}{l}\text { Measles, mumps, pertussis with- } \\
\text { out sequelae. From age } 8 \text { on- } \\
\text { ward, chronic cough and } \\
\text { rhinorrhea. No significant } \\
\text { acute respiratory infection; } \\
\text { chest film negative. No allergies. }\end{array}$ & $2301 / \mathrm{mm}^{3}$ & Normal & 2.7 & 0.3 & 0.6 & 0.7 & 2.5 \\
\hline D. $\mathbf{R}$. & 10 & q & $\begin{array}{l}\text { Ataxia noted on at- } \\
\text { tempting to walk. } \\
\text { Conjunctival telan- } \\
\text { giectasia noted at } \\
\text { age 3. No skin } \\
\text { telangiectasia. }\end{array}$ & $\begin{array}{l}\text { Otitis media at age } 9 \text { led to } \\
\text { adenoidectomy. Postnasal drip } \\
\text { and fever in month before } \\
\text { present study. Sinus films nega- } \\
\text { tive. Allergies to milk and } \\
\text { chocolate. }\end{array}$ & $2012 / \mathrm{mm}^{3}$ & $\begin{array}{c}\text { Bone marrow } \\
\text { biopsy not } \\
\text { performed }\end{array}$ & 3.9 & 0.1 & 0.8 & 0.5 & 3.6 \\
\hline
\end{tabular}




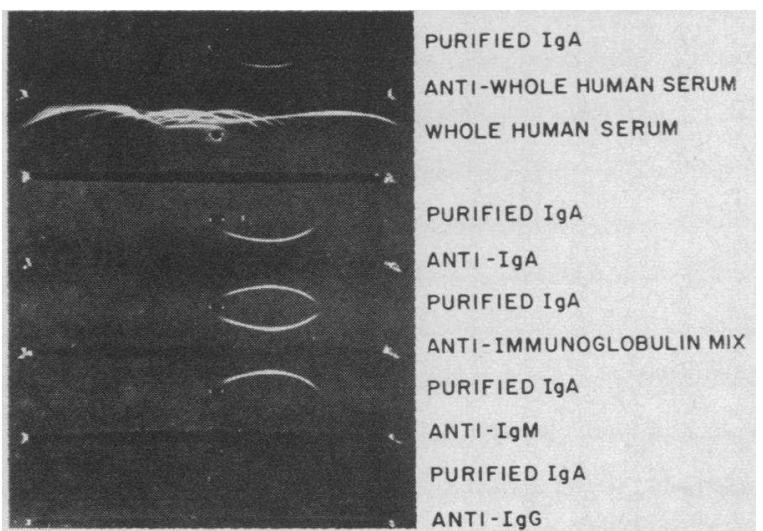

FigURE 1 Immunoelectrophoretic study of preparation C. No contaminants are detected with anti-whole human serum or with anti-immunoglobulin mix.

amyotrophic lateral sclerosis, five patients with myotonia or paramyotonia congenita, and one patient with chronic myelogenous leukemia.

Mcasurement of serum immunoglobulin concentrations. Immunoglobulin concentrations were measured by a specific immune precipitation technique $(14,15)$. Standard sera were kindly supplied to us by Dr. John Fahey. Normal values with this system and these materials were established with a panel of 50 control sera.

\section{Preparation of labeled proteins}

$I g G$. IgG was obtained by diethylaminoethyl (DEAE)cellulose chromatography by a method similar to that described by Fahey, McCoy, and Goulian (16). Fresh, normal human serum was dialyzed against $0.005 \mathrm{~m} \mathrm{pH}$ 8.0 phosphate buffer and chromatographed in a DEAE column with the same buffer. The initial protein peak obtained was utilized for isotopic labeling; this protein fraction contained no detectable contaminants in Ouchterlony double diffusion studies.

$\operatorname{Ig} M$. IgM was isolated by block electrophoresis and Sephadex chromatography as in the procedure utilized by Barth, Wochner, Waldmann, and Fahey (17). Fresh, normal serum was concentrated and electrophoresed in a polyvinyl chloride, ${ }^{1}$ polyvinyl chloride-polyvinyl acetate copolymer block ${ }^{2}$ (sodium barbital buffer, $\mathrm{pH}$ 8.6) for $18 \mathrm{hr}$. The gamma globulin region of the block was eluted with saline and concentrated by ultrafiltration; the protein was then dialyzed against $1.0 \mathrm{M} \mathrm{NaCl}, 0.1 \mathrm{M}$ Tris- $\mathrm{HCl}, \mathrm{pH} 8$ buffer, and placed on a Sephadex G-200 column ${ }^{3}$ equilibrated with the same buffer; the first half of the initial peak thus obtained was used for labeling.

\footnotetext{
${ }^{1}$ Geon Resin, B. F. Goodrich Chemical Co., Niagara Falls, N. Y.

2 Pevikon, Superfosfat, Fabrika, Aktiebolog, Stockholm, Siveden.

${ }^{3}$ Sephadex, Pharmacia Fine Chemicals, Inc., Piscataway, N. J.
}

The material contained no detectable contaminants in Ouchterlony double diffusion studies.

$\operatorname{Ig} A$. $\operatorname{IgA}$ was isolated by starch-block electrophoresis with serum obtained from a patient with an isolated elevation of $\operatorname{IgA}$ (courtesy of $\mathrm{Dr}$. A. Solomon); this serum abnormality has been unassociated with other evidence of disease over a period of several years. $6 \mathrm{ml}$ of serum was electrophoresed in polyvinyl chloride, polyvinyl chloride-polyvinyl acetate copolymer block for $18 \mathrm{hr}$. $1 \mathrm{~cm}$ strips toward the anodal side of the origin were separately eluted with saline and analyzed for protein content. Preparation A contained IgA with an IgG contamination of approximately $15 \%$, as shown by radial immunodiffusion in agar. IgG was the only significant contaminant detected by Ouchterlony studies with antiserum to whole human serum. Preparation B contained IgA with a transferrin contaminant of approximately $11 \%$. Trace amounts of beta lipoprotein and $\alpha$-2-macroglobulin were also demonstrated in preparation B. Preparation of $\mathrm{C}$ contained no detectable contaminants by immunoelectrophoresis (Fig. 1) and Ouchterlony analysis using antisera directed against a variety of plasma proteins. Ultracentrifugal studies with saline solvent showed a single $6.6 \mathrm{~S}$ peak in preparation $\mathrm{B}$, and the major $6.6 \mathrm{~S}$ peak and minor $9 \mathrm{~S}$ and $11 \mathrm{~S}$ peaks in preparation A. (Ultracentrifugal studies were done several weeks after the preparation of the protein.)

Labeling of proteins and radioimmunoelectrophoresis. All proteins were labeled with ${ }^{131} \mathrm{I}$ or ${ }^{125} \mathrm{I}$ by the iodine monochloride method of McFarlane (18). All preparations were calculated to have an average of less than one atom of iodine per molecule of protein and contained less than $2 \%$ nonprecipitable radioactivity. Normal human albumin was added to each preparation in order to prevent damage due to irradiation.

After labeling, IgA preparations were studied by radioimmunoelectrophoresis. In all preparations, the major band of radioactivity was represented by $\operatorname{IgA}$. In preparation $A$, a small proportion of the radioactivity was associated with IgG, and in preparation B, a small amount of label was associated with transferrin. Preparation A was thus shown to be free of transferrin contaminant, and preparation $\mathrm{B}$ was shown to be free of $\mathrm{IgG}$ contaminant. Preparation C contained no labeled contaminants.

The purified $\operatorname{IgM}$ preparation was also studied by radioimmunoelectrophoresis and contained no labeled contaminants. Labeled IgM was mixed with normal serum and placed over a Sephadex G-200 column; radioactivity appeared in the initial protein peak which thus confirmed labeling of $19 \mathrm{~S}$ components.

Turnover study protocol. Patients were studied on the wards of the National Cancer Institute of the $\mathrm{Na}$ tional Institute of Neurological Diseases and Blindness. Patients were never acutely ill during the period of study, and repeated determinations of serum immunoglobulins were constant, which thus confirmed the presence of steady-state conditions.

Patients were placed on saturated potassium iodide solution in order to block thyroidal uptake of isotope. 


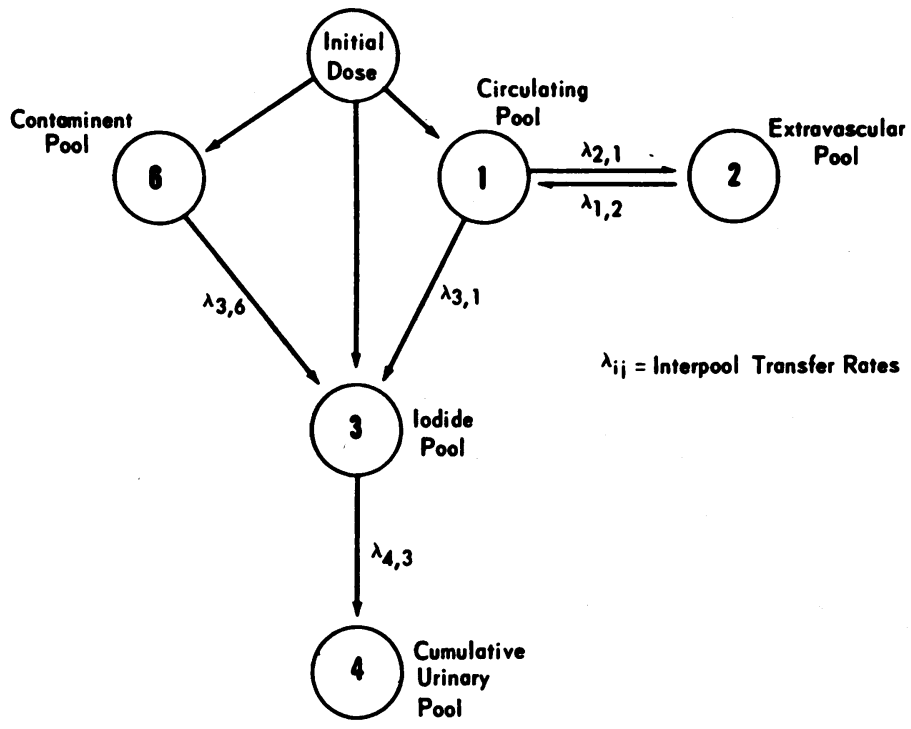

Figure 2 Kinetic model of IgA metabolism. See Methods for explanation.

Isotope injections were done in individual patients sequentially or simultaneously, in each case with ${ }^{125} \mathrm{I}$ or ${ }^{131} \mathrm{I}$ isotopes. Each turnover study was initiated with the injection of 5-30 $\mu \mathrm{c}$ of isotopically labeled protein with a calibrated syringe. A $10 \mathrm{~min}$ sample was obtained for plasma volume determinations. Subsequently, daily samples were drawn for 10-30 days. Complete urine collections were also obtained after the initiation of the study.

Urine aliquots and serum samples were counted in an automatic gamma ray well-type scintillation counter with a thallium-activated sodium iodide crystal with a pulse height analyzer.

Data analysis. Analysis of the IgG and IgM kinetic data was based on the methods of Berson, Yalow, Schreiber, and Post (19) and Pearson, Veall, and Vetter (20). With these methods, the total exchangeable protein pool, the fractional catabolic rate, and the synthetic (turnover) rate were determined.

The $\operatorname{IgA}$ kinetic data were analyzed by a method of compartmental analysis elaborated by Berman, Shahn, and Weiss (21). This method utilizes a digital computer to fit data to compartmental models and was chosen in order to obtain meaningful estimates of catabolic rates in certain instances of rapid catabolism of $\operatorname{IgA}$ protein.

In Fig. 2 is a diagram of the compartmental model which "fit" the IgA turnover data obtained in these experiments. It is seen that the model consists of protein pools (compartments) and intercompartmental transfer constants $\left(\lambda_{1}\right)$ representing the fractional rate of movement of material between compartments. Compartment 1 represents the plasma protein pool, compartment 2 represents the extravascular protein pool, compartment 3 represents the body iodide pool, compartment 4 represents the urinary radioiodide pool, and compartment 6 is a pool, parallel to compartment 1 , which represents contaminant protein having an assigned fractional catabolic rate $\left(\lambda_{3,6}\right)$. Conditions in compartments 1 and 4 were obtained from the $\operatorname{IgA}$ turnover data and were used by the computer to calculate conditions in the remaining compartments as well as the intercompartmental transfer constants. The initial pulse of radioactivity was distributed between compartments 1 and 6 . The best fit of data to the compartmental model was obtained when approximately $15 \%$ of the initial dose was shunted into the contaminant pool (compartment 6) for preparations $A$ and $\mathrm{B}$; this corresponded well with the immunologic analyses of the original protein preparations. No contaminant pathway was necessary for preparation $\mathrm{C}$.

The transfer constant between compartments 1 and 3 $\left(\lambda_{3,1}\right)$ represents the fractional degradation rate or the fraction of circulating IgA catabolized per day. The distribution of IgA between intra- and extravascular pools may be computed from the ratio of the transfer constants between pools 1 and $2\left(\lambda_{12} / \lambda_{21}\right)$. The steady-state synthetic rate is the product of the fraction of the circulating IgA catabolized per day $\left(\lambda_{3,1}\right)$ and the total circulating IgA.

It should be noted that the iodide excretion rate $\left(\lambda_{4,3}\right)$ was specified in the computer program within statistical limits with known experimental values (22). In addition, the fractional catabolic rate of the contaminant proteins in preparations $A$ and $B\left(\lambda_{3,4}\right)$ was specified in computer program within statistical limits with known experimental values $(23,24)$.

\section{RESULTS}

IgG and IgM metabolism. A summary of IgG and $\operatorname{IgM}$ metabolism in ataxia telangiectasia is found in Tables II and III. Serum levels of IgG varied considerably. In two cases, distinctly high levels of IgG were found; these patients had been subject to recent and recurrent infection. One instance of abnormally low IgG was found; this patient had been subject to respiratory infection in 
TABLE II

IgG Metabolism in Ataxia Telangiectasia

\begin{tabular}{|c|c|c|c|c|c|c|c|}
\hline Subject & $\begin{array}{c}\text { Serum } \\
\text { IgG }\end{array}$ & $\begin{array}{l}\text { Plasma } \\
\text { volume }\end{array}$ & $\begin{array}{c}\text { Total } \\
\text { circulating } \\
\text { IgG }\end{array}$ & $\begin{array}{c}\text { Total } \\
\text { exchangeable } \\
\text { IgG }\end{array}$ & $\begin{array}{c}\text { Survival } \\
\text { t }\end{array}$ & $\begin{array}{l}\text { Fraction of } \\
\text { circulating IgG } \\
\text { catabolized } \\
\text { per day }\end{array}$ & $\begin{array}{l}\text { Synthetic } \\
\text { rate }\end{array}$ \\
\hline & $m g / m l$ & $m l / k g$ & $m g / k g$ & $\mathrm{mg} / \mathrm{kg}$ & days & & $m g / k g$ per day \\
\hline G. V. L. & 9.3 & 29.8 & 277 & 644 & 17.3 & 0.093 & 26 \\
\hline P. G. & 5.2 & 29.8 & 154 & 363 & 22.0 & 0.074 & 11 \\
\hline G. N. L. & 11.6 & 32.1 & 372 & 892 & 18.3 & 0.091 & 34 \\
\hline D. R. & 23.6 & 38.0 & 897 & 1870 & 9.3 & 0.155 & 139 \\
\hline G. R. & 25.3 & 41.2 & 1040 & 2990 & 16.5 & 0.121 & 125 \\
\hline Controls (23) & & & & & & & \\
\hline Mean & 12.1 & 42.0 & 494 & 1090 & 22.9 & 0.067 & 34 \\
\hline$\pm \mathrm{sD}$ & \pm 2.6 & \pm 5.8 & \pm 116 & \pm 263 & \pm 4.0 & \pm 0.015 & \pm 11 \\
\hline
\end{tabular}

the distant past, though not in the several years before study. IgG synthetic rates and catabolic rates were within normal limits in the two patients with normal serum IgG levels. In those patients with high serum IgG levels, fractional catabolic rates were increased and, correspondingly, synthetic rates were greatly increased above normal. In contrast, the patient with low serum IgG level had a normal fractional catabolic rate and a synthetic rate approximately two standard deviations below the norm.

IgM levels were normal in three patients and slightly elevated in two patients. The three patients with normal IgM levels underwent turnover studies with labeled IgM and showed normal fractional catabolic and synthetic rates. Distribution of $\operatorname{IgM}$ protein was likewise normal in these patients.

IgA metabolism. The mean serum IgA level in the control patient group $(2.5 \pm 1.4 \mathrm{mg} / \mathrm{ml})$ was close to the established mean in a panel of
50 normal sera $(2.6 \pm 1.1 \mathrm{mg} / \mathrm{ml})$. In one case, an unusually low value was found (patient E.M.), and in one instance, a somewhat high value was found (patient R.McS.). In contrast to the control group, serum $\operatorname{IgA}$ was not detectable in any of the cases of ataxia telangiectasia; in addition, serum which had been concentrated fivefold was also devoid of IgA.

As seen in Table IV, the fractional catabolic rate of $\operatorname{IgA}$ for the control group varied between 14.4 and $33.8 \%$ of the catabolic pool (plasma pool) per day; the average fractional catabolic rate was $25 \%$ per day. Synthetic rates varied between 3 and $55 \mathrm{mg} / \mathrm{kg}$ per day and averaged 24 $\mathrm{mg} / \mathrm{kg}$ per day.

The IgA turnover data of the ataxia telangiectasia group, Table $\mathrm{V}$, fell into two categories. In the first category (represented by patients G.V.L. and P.G.) very rapid catabolism of IgA was observed with computed fractional catabolic rates $\left(\lambda_{3.1}\right) 4$ and 20 times greater than that seen in the

TABLE III

IgM Metabolism in Ataxia Telangiectasia

\begin{tabular}{|c|c|c|c|c|c|c|c|}
\hline Subject & $\begin{array}{l}\text { Serum } \\
\text { IgM }\end{array}$ & $\begin{array}{l}\text { Plasma } \\
\text { volume }\end{array}$ & $\begin{array}{c}\text { Total } \\
\text { circulating } \\
\text { IgM }\end{array}$ & $\begin{array}{c}\text { Total } \\
\text { exchangeable } \\
\text { IgM }\end{array}$ & $\begin{array}{c}\text { Survival } \\
t_{t}\end{array}$ & $\begin{array}{l}\text { Fraction of } \\
\text { circulating IgM } \\
\text { catabolized } \\
\text { per day }\end{array}$ & $\begin{array}{l}\text { Synthetic } \\
\text { rate }\end{array}$ \\
\hline & $m g / m l$ & $m l / k g$ & $\mathrm{mg} / \mathrm{kg}$ & $m g / k g$ & days & & $m g / k g$ per day \\
\hline G. V. L. & 1.96 & 27.1 & 53 & 82 & 7.2 & 0.148 & 7.9 \\
\hline P. G. & 1.63 & 40.9 & 67 & 148 & 6.5 & 0.237 & 15.8 \\
\hline G. N. L. & 1.84 & 27.6 & 51 & 80 & 6.7 & 0.162 & 8.2 \\
\hline \multicolumn{8}{|c|}{ Controls (10) } \\
\hline Mean & 1.45 & 38.5 & 50 & 66 & 5.4 & 0.172 & 8.9 \\
\hline$\pm \mathrm{sD}$ & \pm 0.63 & \pm 8.7 & \pm 25 & \pm 40 & \pm 1.0 & \pm 0.041 & \pm 6.2 \\
\hline
\end{tabular}


TABLE IV

IgA Metabolism in Control Subjects

\begin{tabular}{|c|c|c|c|c|c|c|c|}
\hline Subject & $\begin{array}{c}\text { Serum } \\
\text { IgA }\end{array}$ & $\begin{array}{l}\text { Prepara- } \\
\text { tion }\end{array}$ & $\begin{array}{l}\text { Plasma } \\
\text { volume }\end{array}$ & $\begin{array}{c}\text { Total } \\
\text { circulating } \\
\text { IgA }\end{array}$ & $\begin{array}{c}\text { Total } \\
\text { exchangeable } \\
\text { IgA }\end{array}$ & $\begin{array}{c}\text { Fraction of circulating } \\
\text { IgA catabolized } \\
\text { per day } \\
\left(\lambda_{3,1}\right)\end{array}$ & $\begin{array}{l}\text { Synthetic } \\
\text { rate }\end{array}$ \\
\hline \multirow{3}{*}{ W. T. J. } & $m g / m l$ & & $m l / k g$ & $\mathrm{mg} / \mathrm{kg}$ & $\mathrm{mg} / \mathrm{kg}$ & & $\mathrm{mg} / \mathrm{kg}$ per day \\
\hline & 1.55 & B & 33.1 & 51 & 96 & 0.218 & 11 \\
\hline & & A & 32.2 & 50 & 125 & 0.202 & 10 \\
\hline \multirow[t]{2}{*}{ J. C. } & 2.70 & B & 34.1 & 92 & 172 & 0.237 & 22 \\
\hline & & A & 32.7 & 88 & 229 & 0.228 & 20 \\
\hline \multirow[t]{2}{*}{ W. A. J. } & 3.37 & B & 43.5 & 147 & 353 & 0.144 & 21 \\
\hline & & A & 44.8 & 151 & 409 & 0.165 & 25 \\
\hline J. M. & 2.25 & B & 39.5 & 89 & 200 & 0.274 & 24 \\
\hline R. McS. & 4.95 & B & 38.2 & 189 & 399 & 0.291 & 55 \\
\hline M. E. & 3.80 & A & 34.1 & 130 & 284 & 0.295 & 38 \\
\hline B. A. & 2.70 & A & 33.2 & 90 & 257 & 0.208 & 19 \\
\hline E. M. & 0.19 & A & 45.1 & 9 & 29 & 0.311 & 3 \\
\hline C. $Z$. & 1.30 & A & 42.5 & 55 & 95 & 0.272 & 15 \\
\hline F. W. & 2.50 & A & 47.1 & 118 & 400 & 0.338 & 40 \\
\hline F. M. & 3.96 & $\mathrm{C}$ & 33.1 & 131 & 293 & 0.250 & 38 \\
\hline L. B. & 1.05 & $\mathrm{C}$ & 43.2 & 45 & 89 & 0.187 & 8 \\
\hline Average $\pm 1 \mathrm{sD}$ & $2.53 \pm 1.40$ & & & $95 \pm 53$ & $228 \pm 129$ & $0.252 \pm 0.038$ & $24 \pm 15$ \\
\hline
\end{tabular}

control group. These two patients were studied with all three $\operatorname{IgA}$ preparations with virtually equivalent results. In the second group (patients G.N.L., D.R., and G.R.) the fractional catabolic rates were within the range established by the control patient group.
Calculated maximal IgA synthetic rates obtained by assuming the presence of a serum concentration just below that detectable by the methods used $(0.01 \mathrm{mg} / \mathrm{ml})$ were exceedingly low for all five patients with ataxia telangiectasia (Table V). Mechanism of rapid IgA degradation in $p a-$

TABLE V

IgA Metabolism in Ataxia Telangiectasia

\begin{tabular}{|c|c|c|c|c|c|c|}
\hline Subject & $\begin{array}{l}\text { Prepara- } \\
\text { tion }\end{array}$ & $\begin{array}{l}\text { Serum } \\
\text { IgA }\end{array}$ & $\begin{array}{l}\text { Plasma } \\
\text { volume }\end{array}$ & $\begin{array}{l}\text { Total circulating } \\
\text { IgA* }\end{array}$ & $\begin{array}{c}\text { Fraction of } \\
\text { circulating IgA } \\
\text { catabolized } \\
\text { per day } \\
\left(\lambda_{8,1}\right)\end{array}$ & $\begin{array}{l}\text { Synthetic } \\
\text { rate* }\end{array}$ \\
\hline & & $m g / m l$ & $m l / k g$ & $m g / k g$ & & $m g / k g$ per day \\
\hline \multirow[t]{2}{*}{ G. V. L. } & B & $<0.01$ & 29.6 & $<0.58$ & 5.05 & \\
\hline & $\begin{array}{l}\mathrm{A} \\
\mathrm{C}\end{array}$ & & $\begin{array}{l}29.2 \\
30.4\end{array}$ & & $\begin{array}{l}4.82 \\
6.00\end{array}$ & $<2.50$ \\
\hline \multirow[t]{3}{*}{ P. G. } & B & & 37.3 & & 0.799 & \\
\hline & A & $<0.01$ & 38.2 & $<0.37$ & 0.976 & $<0.25$ \\
\hline & $\mathrm{C}$ & & 37.8 & & 0.914 & \\
\hline \multirow{3}{*}{ G. N. L. } & B & & 32.6 & & 0.179 & \\
\hline & A & $<0.01$ & 33.1 & $<0.40$ & 0.267 & $<0.08$ \\
\hline & $\mathrm{C}$ & & 29.9 & & 0.315 & \\
\hline D. R. & A & $<0.01$ & 36.8 & $<0.37$ & 0.234 & $<0.06$ \\
\hline G. R. & A & $<0.01$ & 41.2 & $<0.41$ & 0.212 & $<0.08$ \\
\hline
\end{tabular}

\footnotetext{
* Assuming $0.01 \mathrm{mg} / \mathrm{ml}$ plasma IgA concentration.
} 


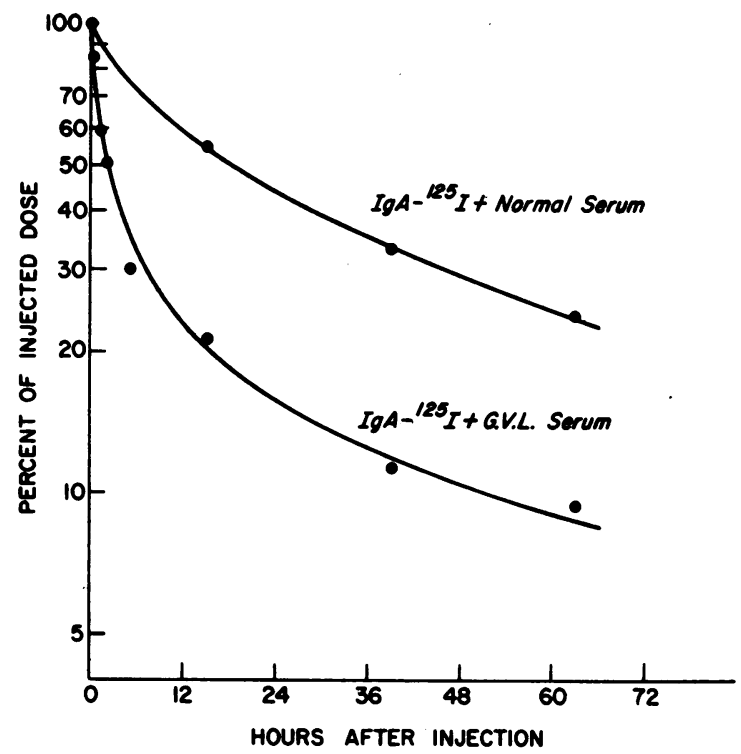

Figure 3 Serum decay curves of labeled $\operatorname{IgA}$ incubated with normal serum and G.V.L. serum. There is a rapid initial disappearance of the labeled $\operatorname{IgA}$ mixed with G.V.L. serum. Later, the rate of disappearance becomes more normal, presumably because immune complexes have already been eliminated.

tients G.V.L. and P.G. A number of studies were performed to determine the cause of the accelerated $\operatorname{IgA}$ catabolism observed in patients G.V.L. and P.G. (a) Labeled IgA was incubated with sera from patients G.V.L. and P.G. overnight at $37^{\circ} \mathrm{C}$ and then injected into control patients. Labeled IgA incubated in G.V.L. serum (two studies) was rapidly catabolized (Fig. 3).
No hypercatabolism was demonstrated with the same IgA preparation incubated with normal serum or serum from patient P.G. (b) Sera from patients with ataxia telangiectasia and controls were mixed with labeled IgA in order to measure the capacity to precipitate IgA. G.V.L. serum, but not other ataxia telangiectasia sera or control sera, proved to have this capacity. Each milliliter of G.V.L. serum could precipitate about $4 \times 10^{-4}$ $\mathrm{mg}$ of $\operatorname{IgA}$. When rabbit anti-IgG was added to the incubation mixture to precipitate soluble complexes of $\operatorname{IgG}$ and $\operatorname{IgA}$, a tenfold increase in $\operatorname{IgA}$ precipitation was obtained. IgG isolated from the serum of G.V.L. also brought about labeled IgA precipitation. Finally, precipitation of labeled IgA by G.V.L. serum was blocked by preincubation of serum with unlabeled IgA. (c) Immune precipitation was also studied with radioimmunoelectrophoresis. Patient sera were electrophoresed and reacted with anti-IgG and other antisera to serum proteins; after development of precipitation arcs, the agar plate was bathed in a medium containing labeled IgA. A radioautograph of the plate subsequently showed labeling of the IgG arc of patient G.V.L.; no other arcs were labeled. Alternatively, G.V.L. serum was electrophoresed and reacted against labeled IgA (placed in the trough); a labeled arc in the gamma region was found by radioautography (Fig. 4). Other ataxia telangiectasia sera showed no evidence of IgA binding by radioimmunoelectrophoresis. (d) Finally, ataxia telangiectasia serum-IgA interaction was studied

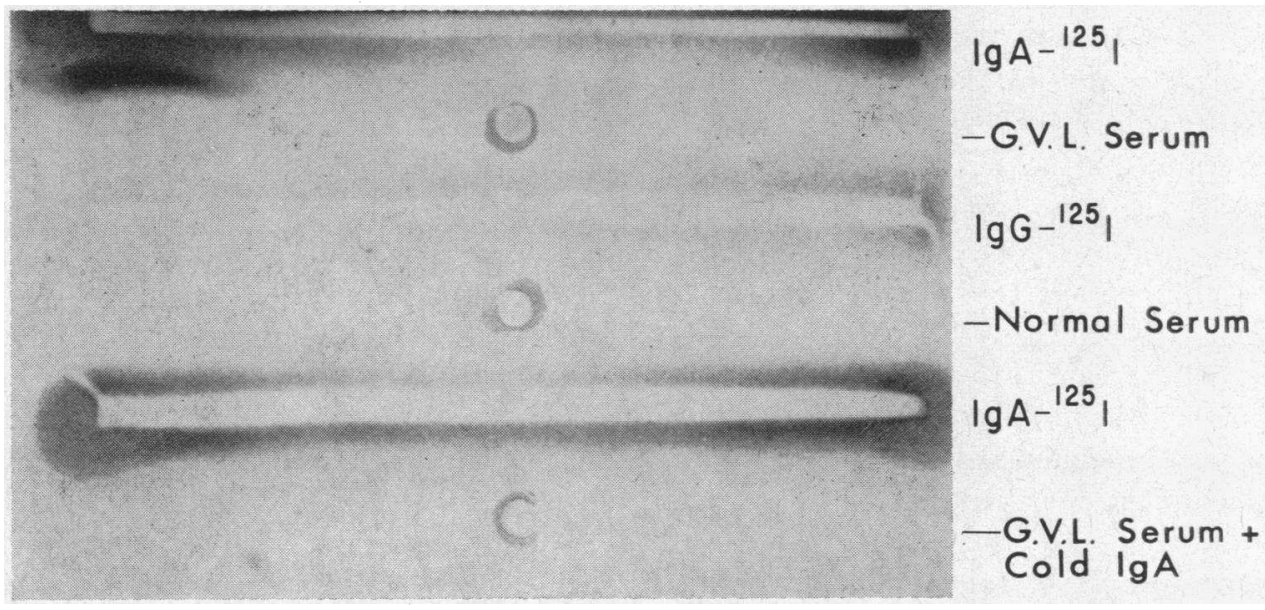

FIGURE 4 Radioimmunoelectrophoresis of G.V.L. serum. Radioprecipitation is seen in the IgG arc when G.V.L. serum is placed opposite $\operatorname{IgA-}{ }^{125} \mathrm{I}$. G.V.L. serum does not react with IgG- ${ }^{125}$ I. Preincubation of G.V.L. serum with cold IgA prevents radioprecipitation. 
TABLE VI

IgA Metabolism in Subjects with Abnormal IgA Levels

\begin{tabular}{|c|c|c|c|c|c|c|c|}
\hline Subject & $\begin{array}{c}\text { Serum } \\
\text { IgA }\end{array}$ & $\begin{array}{l}\text { Prepara- } \\
\text { tion }\end{array}$ & $\begin{array}{l}\text { Plasma } \\
\text { volume }\end{array}$ & $\begin{array}{c}\text { Total* } \\
\text { circulating } \\
\text { IgA }\end{array}$ & $\begin{array}{c}\text { Total }^{*} \\
\text { exchangeable } \\
\text { IgA }\end{array}$ & $\begin{array}{c}\text { Fraction of } \\
\text { circulating IgA } \\
\text { catabolized } \\
\text { per day } \\
\left(\lambda_{8,1}\right)\end{array}$ & $\begin{array}{c}\text { Synthetic } \\
\text { rate* }\end{array}$ \\
\hline & $m g / m l$ & & $\mathrm{ml} / \mathrm{kg}$ & $m g / k g$ & $m g / k g$ & & $m g / k g$ per day \\
\hline A. G. & 41.0 & $\mathrm{C}$ & 50.0 & 2050 & 4820 & 0.318 & 652 \\
\hline A. P. & $<0.01$ & $\mathrm{C}$ & 41.1 & $<0.41$ & $<0.91$ & 0.353 & $<0.08$ \\
\hline B. H. & $<0.01$ & C & 47.0 & $<0.47$ & $<1.0$ & 0.300 & $<0.08$ \\
\hline
\end{tabular}

* Assuming $0.01 \mathrm{mg} / \mathrm{ml}$ plasma IgA concentration for patients A. P. and B. H.

with a modification of the $\mathrm{C}^{\prime} 1 \mathrm{a}$ fixation and transfer test of Borsos and Rapp $(25,26) .{ }^{4}$ This test measures the amount of antibody present by first fixing $C^{\prime} 1$ a to red cells with antibody and then measuring the amount of $\mathrm{C}^{\prime} 1 \mathrm{a}$ fixed by transferring it to a defined red cell hemolysis system containing the other components of complement. The amount of $C^{\prime} 1$ a fixed is directly related to the number of antibody molecules originally present. In the present instance, a special $\mathrm{C}^{\prime}$ la fixation and transfer system was set up, and antibody was detected by specific inhibition of the system. In this system, red cells were coated with IgA (an IgA isohemagglutinin) and mixed with $C^{\prime} 1 a-f i x i n g$ anti-IgA; $\mathrm{C}^{\prime} 1 \mathrm{a}$ fixed was then quantitated and was an indicator of the amount of complement-fixing antiIgA present. This reaction may be inhibited by preincubation of the $\operatorname{IgA}$ isohemagglutinin with a substance that will specifically react with it and thereby prevent binding of the IgA to the cell surface as well as subsequent fixation of $C^{\prime} 1 a$. Inhibition was obtained with both G.V.L. and P.G. serum but not with other ataxia telangiectasia sera or sera of other patients with serum IgA deficiency. It was determined that the G.V.L. serum contained at least $2.6 \times 10^{12}$ anti-IgA molecules per $\mathrm{ml}$ of serum, whereas P.G. serum contained at least $2.1 \times 10^{12}$ anti-IgA molecules per $\mathrm{ml}$ of serum.

In sum, patient G.V.L. was shown to have a circulating serum factor that binds specifically to $\operatorname{IgA}$ and is a $\gamma \mathrm{G}$-globulin. Evidence for a similar factor in the serum of patient P.G. was provided by the $\mathrm{C}^{\prime} 1 \mathrm{a}$ fixation and transfer test.

Metabolism of IgA in patients with IgA myeloma and hypogammaglobulinemia (Table VI).

\footnotetext{
${ }^{4}$ Kindly performed by Dr. T. Borsos, National Cancer Institute.
}

The IgA fractional catabolic rates for the myeloma patient, the hypogammaglobulinemic patient, and the patient with isolated IgA deficiency were within the control range. In the myeloma patient (A.G.) the synthetic rate was $652 \mathrm{mg} / \mathrm{kg}$ per day or about 25 times the mean observed in the control group. The synthetic rates in the patients with no IgA (A.P. and B.H.) were $<0.08 \mathrm{mg} /$ $\mathrm{kg}$ per day or less than $0.32 \%$ of the control mean.

\section{DISCUSSION}

Patients with ataxia telangiectasia have a variable dysgammaglobulinemia, with occasional disorders of IgG and IgM concentration, and a frequent reduction or absence of $\operatorname{IgA}$ in the serum. In the present report, the metabolism of the immunoglobulins was studied in five patients with this disease.

IgG and IgM metabolism in ataxia telangiectasia. IgG metabolism in the five patients studied was variable. Survival of IgG (fractional catabolic rate) was normal in three of the five patients, including the two patients with the marked hypercatabolism of $\operatorname{IgA}$. In two patients (both with somewhat elevated IgG levels), survival of IgG was shortened with fractional catabolic rates greater than three standard deviations above normal values. A similarly increased fractional catabolic rate may be seen in other patients with increased IgG levels, as in multiple myeloma $(23,27)$. However, this may not be thelsole explanation since in patient D.R. the serum IgG level of $23.6 \mathrm{mg} / \mathrm{ml}$ was associated with a fractional catabolic rate of $15.5 \%$ /day; in other cases of hypergammaglobulinemia such catabolic rates are associated with far higher IgG levels (23). Only one patient had a decreased IgG level, a finding sporadically found in other cases of ataxia telangiectasia $(2,6)$; in our pa- 
tient, the decreased IgG level was associated with a somewhat decreased synthetic rate and a normal fractional catabolic rate and was, therefore, a pure synthetic defect.

IgM metabolism was studied in three patients, two of whom had marked hypercatabolism of IgA. Serum levels, total body pools, and fractional turnover rates of this protein were normal. Hence, no abnormality of IgM metabolism was noted in these studies.

Normal IgA metabolism. IgA metabolism was studied in 12 control subjects. Synthetic rates varied between 2.7 and $55.0 \mathrm{mg} / \mathrm{kg}$ per day, and fractional catabolic rates ranged from 14 to $37 \%$ per day. This study of normal IgA metabolism compares roughly with those previously reported by Solomon and Tomasi (28), who obtained fractional catabolic rates of approximately $37 \%$ per day.

It is seen that synthetic rates vary by a factor of 20 , whereas catabolic rates vary by a factor of two at most; this means that differences in serum IgA levels among individuals primarily reflect variations in IgA synthesis and not rates of catabolism. It may be noted that the mean IgA synthetic rate of normal individuals $(24 \pm 15 \mathrm{mg} / \mathrm{kg}$ per day) is of the same order of magnitudes as the mean IgG synthetic rate $(34 \pm 11 \mathrm{mg} / \mathrm{kg}$ per day); hence, the widely differing serum levels of $\operatorname{IgA}$ and $\operatorname{IgG}(2.6 \pm 1.1$ vs. $12.0 \pm 2.6 \mathrm{mg} / \mathrm{ml})$ are caused primarily by differing catabolic rates for these two proteins.

It has now been amply demonstrated that $\operatorname{IgA}$ is a prominent constituent of certain external secretions (i.e., saliva, colostrum, and nasal washings). Studies on the transport of labeled IgA into these secretions are consistent with the view that there is very considerable local production of $\operatorname{IgA}$ with release of IgA directly into the secretions. ${ }^{5}$ The synthetic rates calculated in metabolic turnover studies account for only those $\operatorname{IgA}$ molecules entering the circulating pool; these synthetic rates are therefore probably considerably less than the whole body synthetic rate of $\operatorname{IgA}$, which includes synthesis of IgA destined solely for local secretion.

The normal IgA metabolic data illustrate certain important differences between $\operatorname{IgG}$ and $\operatorname{IgA}$

\footnotetext{
s Strober, W., R. M. Blaese, and T. A. Waldmann. Unpublished observations.
}

catabolism. First, IgG and IgA have similar intra and extravascular distribution ratios, and presumably, therefore, these molecules have equal exposure to catabolic sites. Yet IgA has a higher degradation rate than IgG by a factor of three or four. Second, the fractional rate of IgG catabolism may be affected by serum concentration, i.e., with hypogammaglobulinemia fractional catabolic rates are decreased and with hypergammaglobulinemia fractional catabolic rates are increased (23). $\operatorname{IgA}$ catabolism is not apparently affected by concentration per se since the catabolic rates in subjects in the present study with low or absent IgA (without antibody to $\operatorname{IgA}$ ) have normal fractional catabolic rates, and a subject with IgA myeloma likewise has a normal fractional catabolic rate. The differences in the catabolism of IgG and IgA imply that the catabolic mechanisms are unique for each of these proteins and are determined by the $\mathrm{H}$-chain moieties of the molecules.

IgA metabolism in ataxia telangiectasia patients. Turnover studies in the patients with ataxia telangiectasia demonstrate that the serum IgA deficiency in ataxia telangiectasia is predominantly caused by decreased synthesis, with the additional factor of hypercatabolism observed in two of the cases. Synthetic rates could not be truly calculated since no serum IgA was detected; however, if one assumes an $\operatorname{IgA}$ concentration of $0.01 \mathrm{mg} / \mathrm{ml}$ (the maximal amount undetected), maximum synthetic rates are found which vary from 0.08 to 2.5 $\mathrm{mg} / \mathrm{kg}$ per day. Fractional catabolic rate in patient G.V.L. was $500 \%$ per day and in patient D.G. $90 \%$ per day. In the other three patients (G.N.L., D.R., and G.R.) normal survival was observed (mean: $23 \%$ per day). It should be emphasized that the observed shortened survivals cannot, in themselves, explain the serum IgA levels found; even in the patient with a fractional catabolic rate of $500 \%$ per day the maximum synthetic rate possible would be approximately 2.5 $\mathrm{mg} / \mathrm{kg}$ per day, still only $10 \%$ of the mean synthetic rate of the control group. Thus, a severe synthetic defect is seen in all of the patients studied and constitutes the most consistent and important metabolic finding.

The observed hypercatabolism of $\operatorname{IgA}$ in some patients with ataxia telangiectasia would appear to be due to the presence of a circulating factor which results in rapid elimination of the labeled 
$\operatorname{Ig}$ A. That this circulating factor is an antibody is supported by the fact that precipitation of labeled $\operatorname{IgA}$ was obtained with the IgG of the patient G.V.L. and not with any other serum protein. Moreover, the precipitation reaction had specificity in that labeled IgG, IgM, or albumin was not precipitated in radioimmunoelectrophoresis studies. Evidence for the presence of antibody in patient P.G. is less complete. Here no radioactive immunoelectrophoretic band could be seen, but P.G. serum specifically reacted with $\operatorname{IgA}$ in the $C^{\prime} 1$ a fixation and transfer test. We conclude that circulating antibodies are quite likely present in patient G.V.L. and probably present in patient P.G.

The appearance of anti-IgA antibodies in patients deficient in IgA parallels the findings of several authors who have found circulating Gmspecific and non-Gm-specific anti-IgG within the IgM immunoglobulin class. This has been found in patients after repeated blood transfusions (29), after receiving gamma globulins (30), or may occur without any known antigenic exposure (30, 31 ). In the latter instance, sensitization by placentally transferred IgG has been postulated (31).

Anti-IgA antibodies in these patients with ataxia telangiectasia may have developed from previous exposure to parenterally administered gamma globulin. Patient G.V.L., but not patient P.G., received gamma globulin injections in the past. Since IgA turnover studies followed IgM and IgG turnover studies in time, it is possible that sensitization occurred with small (indeed, undetectable) amounts of IgA contaminating IgM and IgG preparations used in the turnover experiments.

The patients with rapid IgA catabolism represent the first instance of an alteration in immunoglobulin survival caused by a circulating antibody. The appearance of such antibodies illustrates the fact that administration of immunoglobulins to dysgammaglobulinemic patients may not be possible since these patients can still produce antibodies to the deficient protein. The ability to give gamma globulin to agammaglobulinemic patients may, in part, be related to the fact that such patients cannot form antibodies in sufficient concentration to affect the survival of the injected materials.

\section{ACKNOWLEDGMENTS}

The authors wish to thank Dr. W. King Engel for allowing us to study his patients, Miss Dolores Houston and
Miss Marion Matthews for technical assistance, and Drs. Mones Berman and Marjorie Weiss for assistance in using the SAAM 22 computer program.

\section{REFERENCES}

1. Thieffry, St., M. Arthuis, J. Aicardi, and G. Lyon. 1961. L'ataxie-télangiectasie (7 observations personnelles). Rev. Neurol. 105: 390.

2. Peterson, R. D. A., M. D. Cooper, and R. A. Good. 1966. Lymphoid tissue abnormalities associated with ataxia-telangiectasia. Am. J. Med. 41: 342.

3. Fireman, P., M. Boesman, and D. Gitlin. 1964. Ataxia telangiectasia. A dysgammaglobulinaemia with deficient gamma-1-A (beta-2-A) globulin. Lancet. 1: 1193.

4. Young, R. R., K. F. Austen, and H. W. Moser. 1964. Abnormalities of serum gamma $1 \mathrm{~A}$ globulin and ataxia telangiectasia. Medicine. 43: 423

5. Dunn, H. G., H. Meuwissen, C. S. Livingstone, and K. K. Pump. 1964. Ataxia-telangiectasia. Can. Med. Assoc. J. 91: 1106.

6. Eisen, A. H., G. Karpati, T. Laszlo, F. Andermann, J. P. Robb, and H. L. Bacal. 1965 Immunologic deficiency in ataxia telangiectasia. New Engl. J. Med. 272: 18.

7. Rosenthal, I. M., A. S. Markowitz, and R. Medenis. 1965. Immunologic incompetence in ataxia-telangiectasia. Am. J. Diseases Children. 110: 69.

8. Ammann, P., V. Lopez, R. Bütler, and E. Rossi. 1965. Das Ataxie-Teleangiektasie-Syndrom (Louis-BarSyndrom) aus immunologischer Sicht. Helvet. Pacdiat. Acta. 20: 137.

9. Shuster, J., Z. Hart, C. W. Stimson, A. J. Brough, and M. D. Poulik. 1966. Ataxia telangiectasia with cerebellar tumor. Pediatrics. 37 : 776.

10. Jeune, M., F. Freycon, I. Covette, R. Carron, and M. Michel. 1964. Ataxie télangiectasie-Etude clinique et immunologique d'une observation. Pédiatrie. 19: 735.

11. Epstein, W. L., H. H. Fudenberg, W. B. Reed, E. Boder, and R. P. Sedgwick. 1966 Immunologic studies in ataxia-telangiectasia. Intern. Arch. Allergy Appl. Immunol. 30: 15 .

12. Boder, E., and R. P. Sedgwick. 1958. Ataxia-telangiectasia. A familial syndrome of progressive cerebellar ataxia, oculocutaneous telangiectasia and frequent pulmonary infection. Pediatrics. 21: 526.

13. Centerwall, W. R., and M. M. Miller. 1958. Ataxia, telangiectasia, and sinopulmonary infections: a syndrome of slowly progressive deterioration in childhood. A.M.A. J. Diseases Children. 95: 385.

14. Fahey, J. L., and E. M. McKelvey. 1965. Quantitative determination of serum immunoglobulins in antibodyagar plates. J. Immunol. 94: 84.

15. Mancini, G., J. P. Vaerman, A. O. Carbonara, and J. F. Heremans. 1964. A single-radial-diffusion method for the immunological quantitation of proteins. In Protides of the Biological Fluids. Proceedings of the 11th Colloquium, 1963. H. Peeters, editor. Elsevier Publishing Co., Amsterdam. 370. 
16. Fahey, J. L., P. F. McCoy, and M. Goulian. 1958. Chromatography of serum proteins in normal and pathologic sera: the distribution of protein-bound carbohydrate and cholesterol, siderophilin, thyroxinbinding protein, $\mathrm{B}_{12}$-binding protein, alkaline and acid phosphatases, radioiodinated albumin and myeloma proteins. J. Clin. Invest. 37: 272.

17. Barth, W. F., R. D. Wochner, T. A. Waldmann, and J. L. Fahey. 1964. Metabolism of human gamma macroglobulins. J. Clin. Invest. 43: 1036.

18. McFarlane, A. S. 1958. Efficient trace-labelling of proteins with iodine. Nature. 182: 53.

19. Berson, S. A., R. S. Yalow, S. S. Schreiber, and J. Post. 1953. Tracer experiments with $\mathrm{I}^{132}$ labeled human serum albumin: distribution and degradation studies J. Clin. Invest. 32: 746.

20. Pearson, J. D., N. Veall, and H. Vetter. 1958. A practical method for plasma albumin turnover studies. Strahlentherapie. 38: 290.

21. Berman, M., E. Shahn, and M. F. Weiss. 1962. The routine fitting of kinetic data to models: a mathematical formalism for digital computers. Biophys. $J$. 2: 275 .

22. Takeda, Y., and E. B. Reeve. 1962. Distribution and excretion of $\mathrm{I}^{12 \mathrm{x}}$ iodide in men on pharmacologic doses of iodides. J. Lab. Clin. Med. 60: 944.

23. Solomon, A., T. A. Waldmann, and J. L. Fahey. 1963. Metabolism of normal $6.6 \mathrm{~S} \gamma$-globulin in normal sub- jects and in patients with macroglobulinemia and multiple myeloma. J. Lab. Clin. Med. 62: 1.

24. Awai, M., and E. B. Brown. 1963. Studies of the metabolism of $\mathrm{I}^{132}$-labeled human transferrin. J. Lab. Clin. Med. 61: 363.

25. Borsos, T., and H. J. Rapp. 1965. Hemolysin titration based on fixation of the activated first component of complement: evidence that one molecule of hemolysin suffices to sensitize an erythrocyte. J. Immunol. 95: 559.

26. Borsos, and H. J. Rapp. 1967. Symposium on Research in Asthma and other Allergic Disorders, Denver, Colo. In press.

27. Lippincott, S. W., S. Korman, C. Fong, E. Stickley, W. Wolins, and W. L. Hughes. 1960. Turnover of labeled normal gamma globulin in multiple myeloma. J. Clin. Invest. 39: 565.

28. Solomon, A., and T. B. Tomasi, Jr. 1964. Metabolism of IgA $\left(\beta_{2 \mathrm{~A}}\right)$ globulin. Clin. Res. 12: 452. (Abstr.)

29. Allen, J. C., and H. G. Kunkel. 1966. Antibodies against $\gamma$-globulin after repeated blood transfusions in man. J. Clin. Invest. 45: 29.

30. Stiehm, E. R., and H. H. Fudenberg. 1965. Antibodies to gamma-globulin in infants and children exposed to isologous gamma globulin. Pediatrics. 35: 229.

31. Wilson, J. A., and A. G. Steinberg. 1965. Antibodies to gamma globulin in the serum of children and adults. Transfusion. 5: 516 . 